Archaeological Journal

\title{
What is a Town?
}

\section{Thomas Kerslake}

To cite this article: Thomas Kerslake (1877) What is a Town?, Archaeological Journal, 34:1, 199-211, DOI: $10.1080 / 00665983.1877 .10851777$

To link to this article: http://dx.doi.org/10.1080/00665983.1877.10851777

曲 Published online: 14 Jul 2014.

Submit your article to this journal 중

Q View related articles $₫$ 


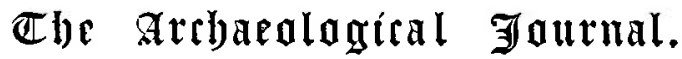

\author{
SEPTEMBER, 1877 . \\ WHAT IS A TOWN? \\ BY THOMAS KERSLAKE.
}

When it is asked, what sort of a place is some "Northport," or "Southlury," or "Mudford," or "Sand. bridge?"- is it a city, or a borough, or a town, or a village?-if the answer should be that "it is a town," or perhaps more definitely, "it is a market town," we-at least, in South Britain-hear the word "town" in the sense in which it is here proposed to consider it.

The story of the west-country clown, who was laughed at because he "could not see the town for the houses," is very unjust to the clown. His blindness is unconsciously shared, not only by the broad majority of his betters, but even by the learned themselves. The "town is to be found neither in books nor in houses, but in the streets :" and has thus been hitherto undiscerned by those who have sought it. In one respect the countryman was wiser than the learned : he saw the mote that caused his blindness. The houses must be abstracted from our thoughts before we can perceive the original town. The houses have been replaced many times over and over again. Even the most ancient churches, abbeys, or cathedrals, are often comparatively late additions to the town. It is the ground plan of the highways and byeways which is the greatest antiquity of the typical or proper town.

Indeed, this particular class of our social concentrations seems to have been the very one that has been hitherto ignored by those who have professed to give us any account of the origin of the various kinds of our condensed populations that are usually included under the

ror. $\operatorname{xxXIV}$ (No. 135). 
broader sense of the word "town." The learned seem to have come to what they deem to be a settlement of the etymology and meaning of the word, which has entirely excluded from their consideration the limited use of it that is here referred to. They have decided that it is the "tun" of the Anglo-Saxon Dictionaries, having the special meaning "an inclosed place," and that it not only therefore describes fortified towns or boroughs, but is still visible in the very many names of English places which end in "ton." In this last position they are probably right; but the names so labelled are far too numerous, and the great majority of the places are teo unimportant, to have ever belonged to that class here proposed to be looked at as being specially called "towns." Most of the places ending in "ton" are, and always have been, the merest rural villages, or more often hamlets. Inclosures they may have been from the beginning, being, in fact, the homesteads of the clans, or families, or tribal settlements, of the original colonies. Such places do not, however, satisfy the more conspicuous and limited meaning of the word "town" above defined; as when it is used to distinguish a community of the second class from one of the first class-a city or borough - on the one hand, or from one of the third class-a village or hamlet-on the other.

Our political and social antiquaries seem to have been content to look no farther back than to the military condition of the colonists for the earliest motive or initial principle of a town: that towns were first of all either themselves the fortified inclosures of governing powers, or that they sprang up under the shelter and protection of some baronial stronghold. To this they add that, in after times, the cathedral, or great monastery, became another attracting centre or cause of such communities; offering, as these no doubt did, a protecting and fostering influence, which by that time had become at least the rival of physical military protection. Mr. Kemble, in the chapter headed "The 'Towns"" in his most instructive work, The Saxons in England, " although, as might have been expected, he has developed them with the great store of learning at his command, has been content with these

\footnotetext{
${ }^{1}$ Vol. ii. pp. 262-341.
} 
three sources of the existence of our towns, which may be shortly described as the municipal, the baronial, and the ecclesiastical.

With deference, however, it is presumed to think that the unmixed ideal "town," as distinguished, on the one side from cities and walled boroughs, and on the other from the inclosed settlements of early rural colonists, now perhaps villages and hamlets, or the homesteads of manors; had an actual existence-must from a natural or social exigence have existed--independent of these three artificial causes. That, although in aftertimes the original town has in many cases had one or more of these other causal agents grafted upon it, or has even been absorbed into them-has become fortified because of its strategic value; or its privileges have been both protected and overawed by the stronghold; or nourished and aggrandized by the growth of its missionary cell into a rich and powerful religious college-in its natural or unmixed state it was essentially uninclosed. In fact, its chief cause or initial purpose required that it should be a neutral spot and open to all comers.

But this state of it must not be expected to be found in books or records, all of which it pre-existed. Early written history almost entirely deals with war and defence. But the booty of war and the objects of defence must have preceded war and defence themselves. If war fills the pages of history; both the many antecedent ages, and the centuries of years themselves from which history has been gleaned, must have been filled in with a broad background, diapered with the variously chequered though uniformly recurrent incidents of ordinary life: not perhaps so much unlike our own condition as we are apt to think from the foreshortened backward view, of the more prominent events that overshadow them, which we get from history. The story-very likely a true one-that on the morning of Naseby a gentleman with his hounds was met by the King with his army, will be remembered as continuing this constant pacific subtexture of human affairs down towards our own times. The results of peaceful production and of, at least rudimentary, commerce, must have already existed before the attempts to seize, and the struggles to keep them. 
The pacific or commercial cause of these mere towns is however not only manifest in their obvious necessity - the positive need, from the very first, of places of mutual resort and intercourse between primitive neighbouring village settlements-but may, it is thought, be discerned in a general characteristic, still to be observed in the ground-plans of most of them. The typical contrast of plan between the ancient English city and the ancient English town must be familiar to even the most unobservant wayfarer. The ancient part of a city almost always still consists of a boundary, originally fortified, approximating to a quadrangle; with four principal entrances admitting four ways that meet in a rectangular cross at the centre. All the subordinate streets more or less obey this rectangular precedent, and even late accretions repeat the square masses. But a town has three principal approaches, meeting at a central triangular space, usually occupied by the market-where a market survives-and the smaller streets often acknowledge a governing tendency to feather off into repetitions of this triangular rule. In fact, whilst the original city was designed of set purpose, and fortified, and the primitive village or tribal settlement was planted or colonized, and probably inclosed, at a chosen spot; the town, on the contrary, has grown up between them spontaneously, out of a mere natural exigence.

As long as two neighbouring rural settlements desired to meet, either for conference or barter, any spot on the interval or path between them would serve; and no accustomed or appointed place of meeting would be necessary. They had only to approach each other until they met. But when the intercourse was to be between three or more, the point where two paths or trackways join into one would, from obvious convenience or expediency, become the appointed place of meeting. Conferences of this kind, where the parties are more than two, would soon bring into action a new principle. The presence of two buyers to one seller, or of two sellers to to one buyer, constitutes the substratum of Marketprice-the first rudiment of trade. These triangular spots, therefore, are the first cradle of that giant whom we now see, with his seven-league boots-ships and 
railways-striding across oceans and continents. This new principle, which we now call commerce, once quickened, would induce a frequent repetition of the gatherings at these places, and they would speedily become periodical - that is, they would be markets, fairs, and perhaps religious festivals. The want of some permanent shelter would next be felt and supplied, afterwards continued to our day in the market cross, now being developed into the market-house with the townhall. Close at hand would be pitched the refieshment booth, afterwards to become the more permanent inn. Then would follow the shoeing forge, the general shop, and the other appliances not only for the occasional wants of congregated numbers, but also for a supply of exotic home comforts until the next meeting. All this change and progress would meanwhile leave their first cause, the forked trackway, as they found it, and as we now find it. In aftertimes the missionary would take advantage of these central assemblages of the country district, and hold field-preachings in one of the three interval spaces left by the forked road; and his teachings would afterwards be perpetuated in the church, named perhaps after some famous apostolic teacher, whose disciple or suffragan he was, or after the name of his predecessor, who had been rewarded for his misconstrued message of peace by martyrdom upon that very spot.

The case of these towns of emergence includes their chief organic function, the market, as already suggested intimately involved in their cause. Not being sought beyond what is written, the origin of markets is usually attributed to special grants, actual or presupposed; but, like other steps in social progress, although of independent origin, political exigency speedily brought them under state control. This, it will be remembered, was the fate of the printing press: also of that greater institution, within which the memory of this native immunity, and the struggle against subjection, still smoulders. As central governments increased in power they purposely restricted the number of places where markets and assemblages of people might be held, both for the enforcement of police supervision against fraudulent sales, and for security against revolt. One of the laws of William 
the Conqueror expressly limits them to cities, walled boroughs, and fortresses. The original markets, therefore, may have been far more numerous than we now find them. A natural centralizing tendency must have since come into action in favour of the superior attractions of those within the cities and boroughs, and in the larger towns. Improvements of roads and in the means of travelling, and the passing of markets out of this original natural free or optional state into that of subjection to royal prerogative and manorial right, have no doubt greatly restricted their numbers. These original markets are in many cases, probably, still represented by the village green, with its maypole sometimes yet standing. For even here the fairs, revels, and annual festivals, and the occasional pitching of wild-beast-shows, conserve that sense of a public right to assemble there which has prevented their inclosure.

This initial triangular rule is still wonderfully persistent even in those towns which have grown up to be the rivals of cities and even of capitals. It is not only still to be traced in the ancient nucleus around which the largest of our towns have gathered themselves, hut is often so vigorous as to germinate throughout their most extensive accretions and suburbs. This may be partly due to the approaches from the country having necessarily conformed to the trifold character of their central terminus, and the overflows of the town have naturally flanked the roads already existing. In some cases even the necessary enlargement of the market-place itself, although very great, has continued the triangular form which had been first impressed upon its centre. In the noble example of Nottingham this triangular law is still supreme. In others of the largest towns it may still be made out, although much overlaid, or obscured, or almost obliterated. In Manchester some traces of it may be discerned in the old Market-place, contiguous to the parish-collegiatenow cathedral-church; but, influenced perhaps by remains of Roman streets, the present great town had already assumed the general quadrangular aspect of a city, long before it was tardily promoted to that dignity: or more likely its great sudden growth may have resulted in an analogy with Berlin. At Birmingham also the 
ancient triangular centre is still very conspicuous in "The Bull Ring," a name in which one of its festival purposes has deposed the utilitarian one of "The Market Place." The name "Bull Ring" also remains at the central area at Kidderminster; and in other towns not only in the Midland counties, but in other parts of England.

Good, perfect, and unaltered specimens of this ideal of a town are indeed very frequent all over the kingdom, and three or four at least used to be passed through during a short journey from one city to another. Tewkesbury is a good example; so also Shrewsbury, Faversham, Tiverton, and others; and although Leland failed to discern the general principle which now engages our attention, this characteristic of the plan of a town in one instance attracted his notice. He describes Thornbury, Gloucestershire, as we now see it,- "to the proportion of the letter $\mathrm{Y}$, having first one long Strete and two Hornnes goynge owt of it." 1 This principle is also very obvious at Alcester, Warwickshire; from which it may be inferred that the Roman chester, still remembered in the name, had become desolate, and that travellers already passed by it, without using its forsaken streets, before the adjoining English town arose in the spontaneous manner here suggested. Not many increasing English towns have continued almost to our own time contracted within the limits of chronic fortification; but where this has happened, as at Sandwich,--still confined within an ancient earthen wall similar to that of Wareham-the feathered tendency of the street plan has, by compression, been contorted into some approach to what is called flamboyant.

In many cases the increase of the market, instead of enlarging the triangle, has preferred to overflow into one of its three arms, the one street being much widened to receive it; as at Chipping-Sodbury, Marlborough. Southmolton, and very many towns in the south-west of England. The large square markets resembling the Flemish Grande Place, especially frequent in the north of England-as at Ripon, Richmond, Leyburn, and Darlington-may be a still further development of this same 
method of enlargement by widening one of the three arms. But in both of these classes it will generally be found that two entrances remain at one end, whilst there is only one outlet at the other.

What the numerous "tons" really represent are the centres of the original territorial unit, the colony or tuwnship or tithing which became the constituent of the hundred, and itself afterwards chiefly merged in the rural parish; in which the "tons," although still the merest villages, are now often called the "church-town." Whenever this settlement of the rural tithings or townships into parishes took effect, such of the upsprung towns as had provided themselves with churches of their own made good a share in that arrangement, resolving themselves into one or several independent parishes. But it does not seem likely that a plurality of parishes in a town, even in the old larger towns and boroughs, hands down any original divisions of it, or any planted constitution. Any such intramural plurality of parishes would arise from offshoots or accretions of emergency : constitutional organizations or privileges being superinduced when the community was ripe for them, or powerful enough to obtain them. It is hardly likely that even a municipal borough was, as has been claimed for it, "nothing more than a hundred, or an assemblage of hundreds, surrounded by a moat, a stoccade, or a wall." " Although apparently ignored in written evidences, their growth by successive accretion is attested by an extrinsic monument. The dedications of the churches, in the oldest of our large towns, indicate a succession of different ages, and even of different peoples. The town of Bristol, for example, shews a stratified succession of dedications from the first half of the eighth century (A.D. 741) downwards. And even the chesters, that still preserve their Roman plan and outline, have been materially resuscitated in this progressive manner. Exeter, for example, presents accessions of different ages and nations in the names of the churches; and a reference to a plan in this Journal ${ }^{2}$ will shew the churches accumulated near the arterial centre, by later deposit, with a considerable unoccupied space nearer the

1 Sir F. Palgrare, Engl. Comm., p. 102.

2 Vol. $x x x$, p. 212. 
walls. Dorchester is a smaller example of this. So that although country parishes may have, to a great extent, continued earlier civil divisions of land, those within even the most ancient towns do not transmit any ancient municipal organization, but are rather ratifications of the limits of those for whom the churches had been established, either as chapelries or offshoots of mother churches, or of additional colonies of townsmen. In the case of Exeter the civil division which survived was still later than the parochial; for while the parish boundaries had respected the more ancient line of street, the civic wards are found in accordance with the mediæval deviation from that line, made A.D. 1286.

On the other hand, existing specimens are far from uncommon, of important old towns, of our occasional or undesigned class, that must have grown up since the settlement of rural parishes, still remaining in a parasite condition within the precincts of the parishes, but quite distinct and even remote from the comparatively inconsiderable original head-centre or "ton." The ancient chesters, moreover, are not the only witnesses of the quadrangular result of the artificial or simultaneons design, as contrasted with the spontaneous cause. New Sarum, with its conspicuous "chequers," is an early mediæval one. The plan of Berlin may also be seen in immediate contact with its ancient suburb on the Spree; not to mention the great modern capitals of the new continents and the colonies.

Neither are entirely wanting similar monuments or continuances of the original "tons," or central homesteads of the rural territorial units, from which the present purpose is to discriminate our "towns" of the narrower meaning. The tide of modern life and great highways have rectilineated and nearly obliterated the original character of those that are more commonly seen. But in secluded nooks in the extremities of the land, a stroller is sometimes surprised, on passing through a gate or over a stile, to find that he has really entered a village instead of a farm-yard, as he may have expected. The clustered cottages are spotted about without order, and among them the larger farm-house, with its appendages; one of which at first sight seems to be the church, asserting its 
dignity, not by its situation, nor always by its size, but by the visible evidences of its middle-age ecclesiastical masonry and attributes. In more urbano districts, the manor-house, instead of degenerating to a farm, has grown into a palatial mansion, under whose wing the church remains, a humble but ornamental adjunct, often included within the park fence itself, but with a right of way from the still contiguous but now excluded village.

How then does it happen that the very class of the concentrated communities which are self-grown, and essentially open and neutral, should not only be called by a word which is understood to mean an inclosure, but that it is also so called in emphatic distinction from the other classes which are by their nature planted and inclosed or fortified, and therefore comprehended under the same word "town," but in a wider and more general sense of it? Can it be another example of, what is far more common than suspected, two words of different origins and meanings that have become identical in form? Much political evolution must have preceded the earliest outcrop of social institutions into written evidences, wherein we may expect to find them already in many distinct threads ; and it need not be wondered at if some two of these, on coming into light, should be found to be of one colour. Can it be that the word "town," in our more limited sense, is closely allied to the word "two," as being the place where two roads or trackways joined into one-bivium; that it is a word of the same kindred as "twin," "twig," "twine," "twain," and their numerous fraternity? Places which occupy a similar confluence of two rivers very often have names formed upon this principle: as Twinham. or Tweoxnam, now Christchurch, Hants; Twineham, Sussex; Twickenham, Middlesex; T[w]iverton, Devon; Tw[iv]erton, Somerset; and very many more. In several of the Anglo-Saxon charters are boundary spots called the "twicene," explained by $\mathrm{Mr}$. Kemble, "the angle or point at whjch two roads diverge or meet;" and an inspection of the Ordnance or other road maps will often confirm this interpretation, by showing that obscure places so situated are still often named "Twitchen," or "Twitching."

An example is indeed quoted by Lye, from Alfric's 
Glossary, of the word "Tun-thorp," explained as "Compitum," a meeting of two ways; in which "túm" seems to have the meaning which we want, instead of that of inclosure usually imputed to it; and the word "Tuinweg" of the Saxon Dictionaries, also from Alfric, may be to the like effect. The word "tine," for the forks of a stag's antlers, will also come to mind. Even if it should be conceded that our word "town" proper has a more direct causal connection with the word "two," it would not necessarily withhold from the terminal "ton," which may be in fact another word, its received opposite meaning of an inclosure.

This explanation is confessed to be rather of necessity than choice; but the survival of what is apparently one word, not only with two opposite meanings, but also with two distinctly separate derivations, is believed to be much more common in topographical etymology than has been hitherto believed. If two egg-like stones picked up from one of the pebble beaches of our southern coast should be cracked, one might prove to be a flint and the other a limestone. Starting from two distant matrixes, innumerable tides, many storms, and constant encounters with their rugged companions, have not only finally laid these strange bedfellows side by side, but brought them both to the same complexion at last. So it is with names and words. Perpetually bandied during many ages from mouth to ear and from ear to mouth, many of them, which started on their career in different shapes and from totally different points, have been reduced to the same form with each other.

No doubt many of our towns, as we now find them, have had this general initial principle of an open neutral and spontaneous growth, variously combined with the other causes of origin or development. In some cases they may have occupied or continued the already fortified military post or chester, the seat of some earlier central government; in others they may have sought the shelter of some baronial castle, or the fostering munificence and sanctuary privileges of a great ecclesiastical college. Some of the towns as well as cities and boroughs may have arisen out of the presence of a convenient sea-port, or the accustomed ford of a river have established it as a 
halting place. Others perhaps utilized, or continued a civilized occupation of, the sites of the less elevated hill fortresses, of which we see so many, less fortunate, that owe their present desolation to the remoteness of rivers or of the other needs of a more advanced social state. Some may even be the uninterrupted continuations, from :th unsuspected antiquity, of such assemblages of "pitdwellings" as those which, when abandoned, still excite our passing curiosity under the vague description of "British villages." All that is here proposed is that there was another and more universal cause of towns, independent of, and even antecedent to, all these, which has called into existence a great number, perhaps a majority of them : in fact, has created them as a distinct type, still to be discerned in their ground-plans.

But more often the other agencies are combined, as accidents, with towns of this typical origin and growthhave been added to them. Some towns, already formed by this natural growth, have afterwards been fortified as occupying strategic positions too important to be neglected by central supreme powers; a condition to which that convergence of roads which had been the cause of the towns would itself be a frequent contributory. Many in which had sprung up home-appointed and home-ruling municipal governments have fortified themselves, and not only commanded toleration or defied interference, but also exacted from superior governments recognition, and special privileges or franchises. Others, too populous to be trusted unawed, have had castles raised over them. Perhaps Totnes on the Dart is a good specimen of these compounds of our three-way germ with several other conditions, such as fortifications, added; or Launceston, where there was a " North-gate," a " South-gate," and a "West-gate," still so named, but no trace or possibility that there ever was an East-gate.

In many cases the church, which had taken root in one of the three unoccupied triangular areas or wards--where it is still generally found-has been garrisoned with a chapter of clerks, and become the missionary or baptismal centre of the entire rural district. In a like manner to that by which districts that had been reduced to a central rivil polity had been called "civitates," so were probably 
such christianized circles called "Christianitates," a name which still remains in their centres, the home deaneries of some of our dioceses. The Vale of Evesham was a "Deanery of Christianity," and the deaneries ofExeter, York, Lincoln, Norwich, Leicester, Thetford, Warwick, Totnes, and some others, are still, or until lately have been, called "the Deanery of Christianitie." The secular clerks - the clergy of the world or of the people-in their turn were sometimes replaced by a congregation of monks or regulars. A settlement of either of these orders often had its provincial school of the liberal sciences, in some cases to become famous far beyond its original local purpose, even into distant foreign lands. Sometimes these churches, beneficed by neighbouring benefactors, or enriched by endowments of pious kings or penitent marauders, have thus grown up into the great monastery, and finally completed the material outline of the social group that makes up a town with the crowning grandeur of the minster church. 